DOI: https://doi.org/10.15688/jvolsu11.2017.3.2

UDC 582.47(470.23)

LBC 28.5л6

\title{
THE PINES (PINUS L., PINACEAE) AT PETER THE GREAT BOTANIC GARDEN ${ }^{1}$
}

\author{
Gennadiy Afanas'evich Firsov
}

V.L. Komarov Botanical Institute of the Russian Academy of Sciences, St. Petersburg, Russian Federaition

\author{
Alexandr Gennadjevich Khmarik \\ Saint-Petersburg State Forest-Technical University, St. Petersburg, Russian Federaition
}

\begin{abstract}
This article presents the results of a study of the genus pine (Pinus, Pinaceae) in the Botanical garden of Peter the Great. There are 27 taxa of pines (Pinus), reperesented by 82 trees, in collection of Peter the Great Botanic Garden of the Komarov Botanical Institute RAS (Saint-Petersburg), the oldest of them being up to 125 years old. Pinus peuce, $P$. koraiensis and P. sibirica are the most widely distributed. The tallest tree are $25,0 \mathrm{~m}$ high (P. strobus). They reach the trunk diameter up to $68 \mathrm{~cm}$ (P. strobus). The pride of collection being such rare species from Eastern Asia as P. densiflora and P. densata. The Dwarf Siberian pine (P. pumila) was firstly introduced into general cultivation from here. There are 17 species which produce cones. There are species promising both for repeated (P. edulis Engelm, P. rigida Mill., P. thunbergii Parl.), and primary introduction (P. arizonica Engelm., $P$. culminicola Andersen et Beaman, $P$. henryi Mast.). The continuous monitoring on winter hardiness as well as on steadiness to pests and diseases is necessary, which is especially true in conditions of the global warming of the climate. The investigation of reproductive abilities, quality of seeds and of seed reproduction is of importance. This is necessary to involve the best species and forms into city planting and forest economy.
\end{abstract}

Key words: Pinus, pine, arboriculture, biological peculiarities, Peter the Great Botanic Garden, Saint-Petersburg.

УДК 582.47(470.23)

ББК 28.5 л 6

\section{РОД СОСНА (PINUS L., PINACEAE) В БОТАНИЧЕСКОМ САДУ ПЕТРА ВЕЛИКОГО ${ }^{1}$}

\author{
Геннадий Афанасьевич Фирсов \\ Ботанический институт им. В.Л. Комарова РАН, г. Санкт-Петербург, Российская Федерация
}

\section{Александр Геннадьевич Хмарик}

Санкт-Петербургский государственный лесотехнический университет,

г. Санкт-Петербург, Российская Федерация

Аннотация. В коллекции Ботанического сада Петра Великого Ботанического института им. В.Л. Комарова РАН в Санкт-Петербурге выращивается 27 видов и форм сосны (Рinus L.), представленных 82 экземплярами, в возрасте до 125 лет (P. strobus). По числу особей преобладают: P. peuce, P. koraiensis и P. sibirica. Самые крупные деревья по высоте достигают 25,0 м (Pinusstrobus), по диаметру ствола - 68cм (P. strobus). Гордостью коллекции являются редкие виды, такие как восточноазиатскиеP. densiflora и P. densata. Сосна кедровая стланиковая (P. pumila) впервые здесь была введена в культуру. Образуют шишки17 видов. Среди представителей рода имеются сосны, представляющие интерес как для повторной(P. edulisEngelm, $P$. rigida Mill., P. thunbergii Parl.), так и для первичной интродукции (P. arizonica Engelm., P. culminicola Andersenet Beaman, $P$. henryi Mast.). Необходим постоянный мониторинг, уточнение зимостойкости, а также устойчивости к болезням и вредителям в условиях изменений климата. Важно изучение особенностей семеношения, качества семян, роста и развития семенного потомства. Актуально более широкое внедрение испытанных ( () видов сосны в городское озеленение, лесное и лесопарковое хозяйство. 
Ключевые слова: Pinus, сосна, интродукция растений, биологические особенности, Ботанический сад Петра Великого, Санкт-Петербург.

Введение. Семейство сосновых является наиболее важным семейством среди хвойных во флоре России. При этом ряд видов находится в угрожаемом состоянии и нуждаются в специальных мерах по их сохранению [18]. Сосны известны с древних времен вследствие широкого практического использования их древесины, смолы, семян, а также прекрасных декоративных качеств. Род Сосна - самый крупный род из всех хвойных. Известный эксперт хвойных А. Фаржон признаёт в этом роде 113 видов [13]. В отличие от других родов семейства сосновых, наибольшее разнообразие видов р. Pinus cocpeдоточено в США и Мексике - больше, чем в Китае и Японии [15]. Некоторые виды сосен широко распространены и являются лесообразователями лесов северного полушария. Из них самый широкий ареал имеет сосна обыкновенная (P. sylvestris), распространённая на широких просторах Евразии. Сосна скрученная $(P$. contorta $)$ - самое распространенное хвойное в Скалистых горах Северной Америки. В тоже время, большинство видов имеют очень ограниченный ареал. В очень холодном и сухом климате их рост сильно замедляется, позволяя некоторым деревьям достичь очень значительного возраста. По долговечности сосны - чемпионы среди всех деревьев. Прежде всего, это сосна долголетняя (P. Longaeva D.K. Bailey) с запада североамериканского континента, доживающая до 5 тысяч лет и более. С экономической точки зрения род Сосна самый важный из всех хвойных. Сосна даёт первичные продукты, включающие древесину, древесную массу для производства бумаги, смолу и терпентин. Для многих жителей Земли это ценное пищевое растение. Сосна - очень важная порода деревьев в лесоводстве. Сосна обыкновенная разводится в огромных масштабах на плантациях почти по всей Европе, ею облесены пески Волгоградской области. Кроме того, она широко используется в полезащитном лесоразведении. Первые сведения о произрастании в Аптекарском огороде на Аптекарском острове (сейчас Ботанический сад Петра Великого Ботанического института им. В.Л. Ко- марова РАН, БИН РАН) сосен относятся к 1736 году. В первый Каталог живых растений Сада, который составил и опубликовал Иоганн Сигезбек [21], входила сосна обыкновенная (P. sylvestris) - это вид местной флоры, и сосна кедровая сибирская (P. sibirica), которую многие знают под названием «сибирский кедр». Всего за триста лет, здесь было испытано более 70 разных видов и форм сосны. В Саду мониторинг за представителями этого рода хвойных проводится непрерывно с начала 1980-х гг. Следует иметь в виду, что Сосна рассматривается не только как декоративное дерево, украшающее парковый ландшафт Сада. Это и объект для научных наблюдений. Отдельные фенофазы их сезонного развития являются важными феноиндикаторами календаря природы Ладого-Ильменского дендрофлористического района [3].

Принятые сокращения: вег. - в вегетативном состоянии, выс. - высота, диам. диаметр, дл. - длина, НОС - научно-опытная станция, н.у.м. - над уровнем моря, окрест. окрестности, пл. - образует шишки, пос. посадка (дата посадки на постоянное место в парк), р. - род, уч. - участок, цв. - образует пыльцу, экз. - экземпляр.

Материал и методы. Материалом для исследования послужили растения видов p. Pinus коллекции Ботанического сада Петра Великого БИН РАН. Настоящая работа подготовлена по материалам инвентаризации 2016 года, в рамках подготовки к изданию аннотированного каталога коллекции живых растений открытого грунта Сада. При этом была сделана оценка зимостойкости, состояния и измерены биопараметры каждого дерева (высота, диаметр ствола, диаметр кроны). Использованы данные наблюдений куратора парка-дендрария Г.А. Фирсова с начала 1980-х гг. Размеры и возраст даны на осень 2016 г. Высоту растений до 3,00 м измеряли мерной нивелирной рейкой с точностью до 1 см, до высоты 5,30 м - с точностью до 0,1 м. Высоту более крупных деревьев определяли лазерным высотомером Nikon Forestry Pro с шагом измерения высоты 0,2 м и механическим высотомером Suunto Co. (o/y Suunto Helsinki Patent) 
с точностью до 0,5 м. Оценка обмерзания проводилась по шкале П.И. Лапина [7]. Фенологические наблюдения проводились по методике Н.Е. Булыгина [1, 2], а фенологическая периодизация года принята по Н.Е. Булыгину [3]. Использованы данные метеостанции Санкт-Петербург Государственного Учреждения Санкт-Петербургский центр по гидрометеорологиии и мониторингу окружающей среды с региональными функциями.
Обсуждение результатов. В таблице 1 приводится возраст и размеры представителей р. Pinus в Ботаническом саду Петра Великого, латинские названия приводятся по алфавиту. В графе 2 приводится номер участка (в числителе) и номер экземпляра (в знаменателе). Территория Парка-дендрария разделена на 145 участков. Растения на каждом участке пронумерованы и нанесены на планшеты, что позволяет легко найти их в парке.

Таблииа 1

Биометрические параметры и состояние таксонов (видов и форм) рода Pinus в Парке-дендрарии Сада

\begin{tabular}{|c|c|c|c|c|c|}
\hline Название растений & № уч./ экз. & А, лет & Высота, м & Д, см & Крона, м \\
\hline PinusbanksianaLamb. & $126 / 36$ & 36 & 11,0 & 18 & $5,0 \times 5,5$ \\
\hline PinusbanksianaLamb. & $128 / 27 \mathrm{a}$ & 57 & 21,0 & 27 & $3,5 \times 4,0$ \\
\hline PinusbanksianaLamb. & $128 / 276$ & 57 & 19,5 & 33 & $4,0 \times 7,0$ \\
\hline PinusbanksianaLamb. & $128 / 27 \mathrm{~B}$ & 57 & 15,5 & 21 & $4,5 \times 5,0$ \\
\hline PinuscembraL. & $107 / 20$ & 36 & 7,4 & 11 & $3,7 \times 3,7$ \\
\hline PinuscembraL. & $94 / 113$ & 36 & 7,3 & 19 & $4,5 \times 4,0$ \\
\hline PinuscembraL. & 94/ 114 & 36 & 6,5 & 18 & $4,0 \times 3,7$ \\
\hline $\begin{array}{l}\text { Pinus contorta Dougl. ex Loud. } \\
\text { var. latifolia Engelm. }\end{array}$ & $127 / 10 \mathrm{a}$ & 58 & 17,6 & 25 & $3,5 \times 3,0$ \\
\hline $\begin{array}{l}\text { Pinus contorta Dougl. ex Loud. } \\
\text { var. latifolia Engelm. }\end{array}$ & $127 / 106$ & 58 & 17,0 & 30 & $5,9 \times 7,8$ \\
\hline $\begin{array}{l}\text { Pinus contorta Dougl. ex Loud. } \\
\text { var. latifolia Engelm. }\end{array}$ & $127 / 10 \mathrm{~B}$ & 58 & 17,0 & 22 & $4,7 \times 4,5$ \\
\hline Pinus densata Mast. & $116 / 34$ & 11 & 2,85 & 3 & $2,2 \times 2,3$ \\
\hline Pinus densata Mast. & $116 / 35$ & 11 & 1,70 & 2 & $1,4 \times 1,2$ \\
\hline Pinus densiflora Siebold et Zucc. & $123 / 42$ & 19 & $\sim 4,20$ & 7 & $4,0 \times 3,0$ \\
\hline Pinus densiflora Siebold et Zucc. & $139 / 52$ & 19 & 5,50 & 8 & $3,5 \times 3,5$ \\
\hline Pinus densiflora Siebold et Zucc. & $139 / 55$ & 19 & $\sim 4,50$ & 6 & $2,5 \times 2,3$ \\
\hline Pinus densiflora Siebold et Zucc. & $71 / 34$ & 19 & 1,92 & 4 & $1,2 \times 1,2$ \\
\hline PinusfriesianaWichura & $17 / 114$ & $\sim 11$ & 1,43 & 1 & $0,7 \times 0,7$ \\
\hline PinusfunebrisKom. & $77 / 64$ & 12 & 2,65 & 2 & $1,7 \times 1,5$ \\
\hline Pinus koraiensis Siebold et Zucc. & $25 / 17$ & 58 & 8,4 & 17 & $3,8 \times 3,8$ \\
\hline Pinus koraiensis Siebold et Zucc. & $27 / 13$ & 58 & 14,2 & 26 & $5,4 \times 4,5$ \\
\hline Pinus koraiensis Siebold et Zucc. & $104 / 14 \mathrm{a}$ & 58 & 12,6 & 26 & $4,8 \times 7,0$ \\
\hline Pinus koraiensis Siebold et Zucc. & $104 / 146$ & 58 & 11,4 & 33 & $4,9 \times 8,0$ \\
\hline Pinus koraiensis Siebold et Zucc. & $126 / 40$ & 58 & 6,0 & 9 & $3,0 \times 2,5$ \\
\hline Pinus koraiensis Siebold et Zucc. & $139 / 35$ & 47 & 10,5 & 22 & $4,5 \times 5,0$ \\
\hline Pinus koraiensis Siebold et Zucc. & $36 / 25$ & 58 & 12,4 & 28 & $6,0 \times 6,2$ \\
\hline Pinus koraiensis Siebold et Zucc. & $77 / 45$ & 58 & 11,0 & 26 & $5,8 \times 5,8$ \\
\hline Pinus monticola Dougl. ex D. Don & $116 / 11$ & 60 & 13,6 & 22 & $3,8 \times 3,2$ \\
\hline Pinus mugo Turra & $127 / 4$ & 61 & 1,55 & 1 & $5,5 \times 2,8$ \\
\hline Pinusmugo Turra' Carsten' & $98 / 26$ & $\sim 9$ & 0,31 & - & $0,35 \times 0,35$ \\
\hline $\begin{array}{l}\text { Pinus mugo Turra subsp. rotundata } \\
\text { (Link) Janch. et H. Neumayer }\end{array}$ & $62 / 1$ & 58 & 7,0 & 16 & $7,8 \times 7,2$ \\
\hline Pinus nigra J. F. Arnold & $91 / 28$ & 68 & 14,5 & 36 & $5,0 \times 5,5$ \\
\hline PinuspallasianaD. Don & $106 / 7$ & 57 & 16,0 & 54 & $7,5 \times 9,0$ \\
\hline PinuspallasianaD. Don & $56 / 22$ & $\sim 27$ & 4,86 & 11 & $3,0 \times 3,2$ \\
\hline PinuspeuceGriseb. & $11 / 49$ & $\sim 40$ & 10,2 & 17 & $4,5 \times 6,0$ \\
\hline PinuspeuceGriseb. & $127 / 18$ & $\sim 50$ & 16,5 & 23 & $4,5 \times 5,5$ \\
\hline PinuspeuceGriseb. & $127 / 8$ & $\sim 95$ & 18,8 & 51 & $9,5 \times 9,5$ \\
\hline PinuspeисеGriseb. & $127 / 9$ & $\sim 95$ & 22,0 & 56 & $10,5 \times 9,0$ \\
\hline PinuspeuceGriseb. & $132 / 92$ & $\sim 95$ & 19,0 & 47 & $9,0 \times 10,0$ \\
\hline PinuspenceGriseb. & $133 / 27 a$ & 58 & 18,5 & 26 & $4,5 \times 5,5$ \\
\hline
\end{tabular}


Окончание таблиџьы 1

\begin{tabular}{|c|c|c|c|c|c|}
\hline Название растений & № уч./ экз. & $\mathbf{A}$, лет & Высота, м & Д, см & Крона, м \\
\hline PinuspeuceGriseb. & $133 / 276$ & 58 & 20,5 & 35 & $8,5 \times 8,5$ \\
\hline PinuspeuceGriseb. & $56 / 5$ & 58 & 16,6 & 44 & $9,5 \times 9,5$ \\
\hline PinuspеисеGriseb. & $97 / 26$ & 58 & 18,0 & 31 & $5,5 \times 6,0$ \\
\hline PinuspeuceGriseb. & $97 / 2 \mathrm{~B}$ & 58 & 16,0 & 33 & $8,0 \times 6,5$ \\
\hline PinuspeuceGriseb. & $66 / 16$ & 58 & 16,4 & 42 & $11,0 \times 10,5$ \\
\hline PinuspeuceGriseb. & $97 / 2 a$ & 58 & 17,4 & 38 & $5,0 \times 8,7$ \\
\hline $\begin{array}{l}\text { Pinus ponderosa Dougl. ex C. } \\
\text { Laws. }\end{array}$ & $48 / 43$ & 17 & 3,37 & 6 & $1,7 \times 1,3$ \\
\hline Pinuspumila (Pall.) Regel & $101 / 2$ & 45 & 3,94 & 12 & $5,7 \times 6,0$ \\
\hline Pinuspumila (Pall.) Regel & $128 / 21$ & 45 & 4,40 & 6 & $6,5 \times 5,3$ \\
\hline Pinuspumila (Pall.) Regel & $128 / 28$ & 45 & 2,30 & 2 & $4,9 \times 3,9$ \\
\hline Pinuspumila (Pall.) Regel & $128 / 70$ & 27 & 1,01 & - & $1,8 \times 1,3$ \\
\hline $\begin{array}{l}\text { Pinus pumila (Pall.) Regel f. glauca } \\
\text { Regel }\end{array}$ & $71 / 35$ & 24 & 1,30 & - & $2,8 \times 1,2$ \\
\hline $\begin{array}{l}\text { Pinus pumila (Pall.) Regel f. glauca } \\
\text { Regel }\end{array}$ & $98 / 14$ & 24 & 1,50 & 1 & $3,5 \times 3,0$ \\
\hline PinusresinosaAit. & $128 / 56$ & 43 & 13,0 & 26 & $6,0 \times 5,5$ \\
\hline PinusresinosaAit. & $142 / 35$ & 43 & 13,0 & 29 & $7,0 \times 7,5$ \\
\hline PinusresinosaAit. & $142 / 36$ & 43 & 14,0 & 32 & $8,0 \times 6,5$ \\
\hline PinusresinosaAit. & $142 / 34$ & 43 & 12,0 & 26 & $6,0 \times 6,5$ \\
\hline PinussibiricaDuTour & $127 / 15$ & $\sim 85$ & 17,5 & 42 & $7,0 \times 7,0$ \\
\hline PinussibiricaDuTour & $127 / 16$ & $\sim 85$ & 13,0 & 25 & $6,2 \times 5,5$ \\
\hline PinussibiricaDuTour & $127 / 17$ & $\sim 85$ & 17,5 & 43 & $6,5 \times 7,5$ \\
\hline PinussibiricaDuTour & $36 / 30$ & $\sim 110$ & 15,4 & 38 & $5,0 \times 5,0$ \\
\hline PinussibiricaDuTour & $77 / 55$ & 70 & 8,6 & 21 & $4,0 \times 4,2$ \\
\hline PinussibiricaDuTour & $94 / 203$ & $\sim 25$ & 2,35 & 3 & $1,7 \times 1,5$ \\
\hline PinussibiricaDuTour & $94 / 138$ & $\sim 25$ & 4,30 & 9 & $3,0 \times 3,0$ \\
\hline PinussosnowskyiNakai & $116 / 10$ & 68 & 23,6 & 57 & $8,2 \times 11,0$ \\
\hline PinussosnowskyiNakai & $119 / 5$ & $\sim 48$ & 10,8 & 38 & $10,0 \times 8,8$ \\
\hline PinussosnowskyiNakai & $77 / 63$ & 17 & 2,95 & 5 & $1,9 \times 2,0$ \\
\hline PinusstrobusL. & $131 / 23$ & $\sim 75$ & 16,0 & 31 & $8,0 \times 7,5$ \\
\hline PinusstrobusL. & $36 / 8$ & 68 & 20,4 & 60 & $12,5 \times 11,5$ \\
\hline PinusstrobusL. & $36 / 19$ & 68 & 25,0 & 53 & $12,0 \times 10,6$ \\
\hline PinusstrobusL. & $49 / 7$ & $\sim 125$ & 24,8 & 68 & $14,5 \times 15,5$ \\
\hline PinussylvestrisL. & $118 / 17$ & $\sim 95$ & 16,0 & 48 & $7,6 \times 8,0$ \\
\hline PinussylvestrisL. & $76 / 4$ & $\sim 75$ & 20,0 & 41 & $6,0 \times 7,0$ \\
\hline PinussylvestrisL. & $77 / 20$ & $\sim 60$ & 18,6 & 39 & $5,0 \times 4,0$ \\
\hline PinussylvestrisL. & $77 / 24$ & $\sim 65$ & 17,0 & 39 & $6,0 \times 6,5$ \\
\hline PinussylvestrisL. & $77 / 36$ & $\sim 55$ & 13,0 & 23 & $4,0 \times 4,4$ \\
\hline PinussylvestrisL. & $94 / 94$ & $\sim 60$ & 23,0 & 43 & $7,5 \times 8,0$ \\
\hline $\begin{array}{l}\text { Pinus sylvestris L. f.parvifolia } \\
\text { Carriere }\end{array}$ & $98 / 25$ & 12 & 0,70 & - & $0,45 \times 0,4$ \\
\hline $\begin{array}{l}\text { Pinus sylvestris L. f.parvifolia } \\
\text { Carriere }\end{array}$ & $99 / 30$ & 12 & 0,73 & - & $0,5 \times 0,5$ \\
\hline $\begin{array}{l}\text { Pinus sylvestris L. var. cretacea } \\
\text { (Kalenicz.) Kondr. }\end{array}$ & $56 / 25$ & $\sim 11$ & 3,68 & 4 & $2,0 \times 1,6$ \\
\hline PinustabuliformisCarr. & $17 / 117$ & 11 & 1,98 & 2 & $1,1 \times 1,0$ \\
\hline Pinusuncinata RamondexDC. & $77 / 49$ & 58 & 16,0 & 30 & $5,5 \times 5,0$ \\
\hline Pinusuncinata RamondexDC. & $77 / 69$ & 17 & 2,45 & 3 & $1,5 \times 1,9$ \\
\hline
\end{tabular}

Таким образом, в таблице 1 размещены данные о 82 экземплярах, представляющих 27 видов и форм рода Pinus. По числу особей в коллекции преобладают 3 вида интродуцентов: $P$. peuce -12 , P. koraiensis -8, P. sibirica7 экз. К самым старым деревьям относятся экземпляры P. strobus ( 125 лет) и P. sibirica
( 110 лет). Большинство особей представлены послевоенными экземплярами, выращенными после Великой Отечественной войны, их возраст достигает 70 лет. В последние три десятилетия коллекция пополнилась несколькими новыми таксонами (их возраст варьирует от 9 до 24 лет). Pinus strobes представле- 
на самыми крупными деревьями как по высоте (25,0 м), так и по диаметру ствола (68 см).В Ботаническом саду БИН сосны представлены как в регулярной, так и в пейзажной части парка. Они сформированы в группы, достаточно много отдельно стоящих, солитерных деревьев, которые украшают разные участки парка. Выращиваются следующие виды и формы.

Pinus banksiana Lamb. - Сосна Банкса. Северная Америка. 4 экз. Уч. 128 (3 экз.): всх. 17.05.1960, пос. 28.05.1969 [4]. Уч. 126 : семена из Чехии, Arboretum Mlynany, всx. 1981 г., пос. 1989 г. Пл. В Саду: 1852, 18921898, 1955-1959, 1963 - по настоящее время [9]. Перспективна для лесных культур на наиболее бедных песчаных почвах, а также на каменистых, неблагоприятных для сосны обыкновенной. Семена долго сохраняют всхожесть. Лучше других видов сосен переносит пересадку. Отличается изогнутыми и асимметричными шишками, которые до 15 лет могут оставаться на дереве, и все это время обычно остаются закрытыми. Хвоя короткая (3-4 см дл.) и редко расположенная.

Pinus cembra L. - Сосна кедровая европейская. 3 экз., все представляют один образец. Уч. 94, 107. Семена из природы Чехии. Всх. 1981. Уч. 94: пос. 1995 и 1996 г. Уч. 107: пос. 1999 г. Пл. В Саду: 1796-1938, 1958 - по настоящее время [9]. Ранее вид не отделялся от $P$. sibirica, и точные годы пребывания в коллекции отдельно по каждому из этих двух видов установить трудно. В западноевропейских странах разводится, главным образом, вместо P. sibirica.

Pinus contorta Dougl. Ex Loud. var. Latifolia Engelm. - Сосна скрученная, разновидность широколистная. Группа из 3 экз., уч. 127, один образец. Всх. 12.10.1959, пос. 12.05.1969 [4]. Пл. В Саду: 1879-1887, 1939-?, 1956 - по настоящее время [9]. В природе растет на западе Северной Америки, от Аляски до Калифорнии, от уровня моря поднимаясь в горы до высот 3350 м. Имеет более поверхностную корневую систему по сравнению с сосной обыкновенной. Отличается косыми, несимметричными шишками, а также изогнутой и скрученной хвоей, густозубчатой по краю. Типичная разновидность представляет небольшое дерево до 10 м высотой, часто кустовидное, с шаровидной кроной и короткими ветвями. Разновидность широколистная (var. latifolia) отличается более крупными размерами и используется для создания плантаций лесных культур с целью получения деловой древесины.

Pinus densata Mast. - Сосна гаошаньская. 2 экз., уч. 116. Семена от лорда Ховика, из экспедиции английских ботаников в Китай, горные леса провинции Сычуань. Всх. 2006 г,, пос. 2012 и 2015 г., один образец. Вег. Редкий вид в культуре, в Саду ранее не испытывалась. Декоративна более густой кроной и длинной хвоёй.

Pinus densiflora Sieboldet Zucc. - Coсна густоцветковая. 4 экз. Все представляют собой образец из экспедиции Сада на Дальний Восток, сбор семян в сентябре 1997 г., в Хасанском районе Приморского края, на полуострове Гамова, на скалах вдоль побережья Японского моря, 70 м н.у.м., всх. 1998 г. Уч. 123: пос. 2007 г. Уч. 71: пос. в Японском саду в 2011 г. (здесь подвергается стрижке и формовке как бонсай). Уч. 139: пос. 2007 и 2011 гг. Одно из двух деревьев на уч. 139 (экз. № 52): памятное дерево, посадка писателя А.Г. Битова 2 октября 2007 г. Вид Красной книги РФ [6]. Цв. (в 2014 г. экз. на уч. 123). В Саду: 1940-?, 1966-1974, 1997-2002 [9]. В культуре с 1852 г. [17], до сих пор в Европе редко. Повсеместно разводится в Японии, характерный вид японского ландшафта. В России заслуживает большего распространения. Очень светолюбива, требует хорошего дренажа и не выносит сырых почв. Пригодна для посадок на песчаных дюнах и в скалистых местах. У молодых деревьев крона низкоопущенная, с возрастом приобретает характерную зонтиковидную форму.

Pinus friesiana Wichura - Сосна Фриза, или лапландская. 1 шт., уч. 17, ещё несколько особей этого же образца на питомнике. Растение от Л.В. Орловой и В.В. Бялта, привезено VIII-2009 г. из природных местообитаний Кольского п-ова: окрест. г. Апатиты, Хибинские горы. Пос. 2015 г. Представляет интерес для дендроколлекций и может использоваться для тех же целей, что сосна обыкновенная. Пл. с 2016 г.Близка к сосне обыкновенной и часто считается её подвидом или разновидностью. В природе дерево до 20 м 
высотой, но у верхней границы леса и на побережье Белого и Баренцева морей - невысокий стланик. У этого вида более мелкие шишки и короткая и широкая хвоя.

Pinus funebris Kom. - Сосна погребальная. 1 экз., уч. 77. Семена от Л.М. Пшенниковой из природы Приморского края, окрест. озера Ханка, всх. 2005 г., пос. 2012 г. Внесена в список видов Красной книги РФ [6], на которые следует обратить внимание в отношении их охраны. Вег. В Саду выращивалась: 19401945, 1979-1997 [9]. Вид описан в 1901 г., в культуре недавно, точную дату введения в культуру установить трудно, так как часто не различается от $P$. densiflora и $P$. sylvestris. Дерево до 30 м выс., встречается в природе отдельными узко локальными группами на юге Приморья, а также в Северо-Восточном Китае и Северной Корее.

Pinus koraiensis Sieboldet Zucc. - Coсна кедровая корейская. 8 экз., уч. 25,27 , $36,77,104,123,139$. Все, кроме одного экз. (на уч. 139) включены в книгу А.Г. Головача [4] и представляют один образец, посев 9.01.1959, всх. 6.05.1959. Уч. 27: пос. 1971 г. Уч. 77: пос. 1973 г. Уч. 36:пос. 1973 г. Уч. 104 (2 шт.): пос. 1971 г. Уч. 25: то же, пос. 1975 г. Уч. 123 - тот же образец (отстал в росте), пересажен при реконструкции Парка в 2003 г. с уч. 127, там был пос. А.Г. Головачом в 1973 г. Уч. 139: семена из Канады, всх. 1970, пос. 1981 г. Пл. В Саду: 1861-1879, до 1939 - по настоящее время [9], первые семена от К.И. Максимовича. По длине хвои, размерам шишек и семян превосходит сосну сибирскую кедровую. Дерево до 40 м выс., самый характерный вид хвойных юга российского Дальнего Востока. На юге Приморья в семенные годы урожайность достигает 800 кг с одного гектара, и возможна селекция как орехоплодной культуры. Зимостойка и может успешно выращиваться в европейской части России.

Pinus monticola Dougl. exD. Don - Coсна горная Веймутова. 1 экз., уч. 116. Всх. 8.08.1957, пос. 19.05.1966 [4]. Подвержена стволовому раку, осталось одно дерево из трёх, засыхающее. Раньше давала шишки и всхожие семена. В Саду до этого не испытывалась. В лучших условиях в природе - дереводо 55 (70) м высоты, доживающее до 500- летнего возраста. Разводится в Северной Америке в лесных культурах для получения древесины. В России встречается очень редко. Красивое парковое дерево с узко конусовидной кроной и крупными шишками, которые выделяют много смолы (гораздо крупнее, чем у более известной сосны веймутовой).

Pinus mugo Turra - Сосна горная. Имеет самый длинный список синонимов среди сосен. 1 экз., уч. 127. Семена из Словакии, всх. 17.05.1956, пос. 3.10.1960 [4]. Пл. В Саду: 1816, 1833, 1852-1923, до 1935-1938, 1947 по настоящее время [9]. Впервые упоминается в каталоге Я.В. Петрова [19], потом Ф.Б. Фишер [10] испытал с отрицательным результатом. В условиях современного климата Санкт-Петербурга зимостойка и давно используется в озеленении. Однако, возможно, неустойчива к фитофторе.

Pinus mugo Turra subsp. Rotundata (Link) Janch. Et H. Neumayer - Сосна горная, подвид округлая. 1 экз., уч. 62. Растение от Ю.А. Лукса в 1960-х гг. из НОС Отрадное, это было первое введение здесь в культуру. К 1978 г. достигла 2,0 м выс. [4], сейчас более 6 м выс. Пл. Отличается асимметричными шишками с вздутыми и изогнутыми апофизами. В культуре вероятно давно, вместе с P. mugosubsp. mugo, но раньше не различалась. В природе встречается по сырым местам, на более низких высотах (450750 м) по сравнению с типичным подвидом. Зимостойка и декоративна формой кроны, хорошо подходит для посадок как солитер на светлых местах.

Pinus mugo Turra Carsten ('Carsten's Wintergold')- Сосна горная 'Карстен'.1 экз. Уч. 98. Привитое растение (прививка у корневой шейки) от Н.Г. Цейтина, с западноевропейских питомников, пос. 10.06.2015. Вег. Светло-зелёная хвоя становится золотистой зимой. Растёт медленнее, чем cv. Wintergold, в 10 лет 25 х 50 см. Культивар получен Edwin Carsten, Varel, Germany; интродуцирован Hachmann Nursery, Germany, до 1988 г. [13]. В Саду культивар ранее не испытывался.

Pinus nigra J. F. Arnold - Сосна чёрная. 1 экз., уч. 91. В Саду: 1833, 1858-1862, 1867-1898, 1930-1945, 1949 - по настоящее время [9]. Первые годы отличалась слабой зимостойкостью, после Ф.Б. Фишера [10] мно- 
гократно восстанавливалась, в современной коллекции с 1949 г., зимостойка, с недавних пор образует шишки. На юге России и в зарубежных странах Европы разводится в искусственных лесных насаждениях, в Санкт-Петербурге ценное дерево для дендрологических коллекций.

Pinus pallasiana D. Don - Сосна Палласа, или крымская. Дерево на уч. 106 выращено из семян в 1960 г. [4]. В последние годы стало давать шишки и было получено семенное потомство. Уч. 56: растение из Волгоградской обл., Кумылженский район, лесные культуры на песках в окрест. станицы Кумылженской, 1998 г., пос. 2009 г. Вид Красной книги РФ [6]. В Саду известна с 1955 г. [9]. В культуре с 1790 г., в Англии семенами, полученными от академика П.С. Палласа из Крыма[12]. Дерево до 20 м выс. с широко-яйцевидной кроной и тёмно-серой корой, близка к $P$. nigra. Ареал охватывает Крым, Кавказ, Балканский полуостров, острова Крит и Кипр, запад Малой Азии. Засухоустойчивый и жаростойкий вид, нетребовательный к почвам. Раньше обмерзала в холодные зимы, в условиях современного климата зимостойкость 1.

Pinus peuce Griseb. - Сосна румелийская. 12 экз. на уч. 11, 56, 66, 97, 127, 132, 133. Одним из самых старых является дерево на уч. 132 - пос. 30-х гг. ХХ в. [5]. Очевидно, такими же старыми являются 2 дерева на уч. 127: пос. до 1934 г. Экз. на уч. 97, 56, 133 и уч. 66 представляют один образец: посев 9.01.1959, всх. 25.04.1959. Уч. 97: пос. 1971 г.; уч. 56: пос. 1971 г; Уч. 133: пос. 1973 г.; Уч. 66: пос. 1974 г. [4]. Уч. 11: пос. 1989 г. Хорошо переносит городские условия, в разных местах парка образует самосев, в последние годы более обильно. В Саду: 1887-1888, 1915- по настоящее время [9]. В 1915 г. получена с питомника Кессельринга - стала одной из самых устойчивых и декоративных сосен в парке. Быстрорастущее зимостойкое дерево до 20 (30) м выс. с гор Балканского полуострова, где растёт на высотах 750-2200 м. Достоинством является иммунность к грибным заболеваниям. Крупные многочисленные шишки образуются те только наверху, но и в других частях кроны.

Pinus ponderosa Dougl. Ex C. Laws. Сосна жёлтая орегонская. 1 экз. Уч. 48: семена от А.В. Громадина из природы США, штат Монтана, всх. 2000 г., пос. 2009 г. Вег. В Саду: 1949-1972, многократные повторы [9], зимостойка при посадке в защищённых местах. Относится к высоким деревьям, до 65 м выс. (обычно 20-30 м), на западе Северной Америки почти от уровня моря до 3300 м, предпочитая хорошо дренированные почвы. В районах с подходящим климатом одно из лучших парковых деревьев, интересна для введения в лесные культуры, так как даёт высококачественную древесину. В Санкт-Петербурге представляет интерес как коллекционное растение. Декоративна своей длинной густой хвоёй.

Pinus pumila (Pall.) Regel - Сосна кедровая стланиковая, кедровый стланик. 4 экз., уч. 101, 128 (3 экз.). Уч. 101: семена из природы Якутии, посёлок Чульман, Тимптонский лесхоз, в 1970 г., всх. 1972 г. (растения выращивались во Всеволожском питомнике), пос. М.М. Игнатенко 10.10.1980. Уч. 128: то же, что уч. 101, пос. в тот же день. Свежая подсадка 2014 г. на уч. 128: семена из экспедиции Сада на остров Сахалин, окрест. ЮжноСахалинска, гора Чехова, 950 м н.у.м., всх. 1990 г. Пл. В Саду достоверно испытана Ф.Б. Фишером [10] в 1833 г., далее около 18401916, 1937-1941, 1948 - по настоящее время [9]. Введена в культуру Ботаническим садом БИН [8].

Pinus pumila (Pall.) Regelf. glauca Regel - Сосна кедровая стланиковая, ф. сизая. 2 экз., представляют один образец, уч. 71, 98. Растение от С.И. Чабаненко в мае 1998 г. из ботанического сада Южносахалинска (семена из природы острова Кунашир, склоны вулкана Головнина, всх. 1993 г.). Уч. 98: пос. 2004 г. Уч. 71: пос. 2012 г. Пл. В Саду ранее не испытывалась. В культуре в Западной Европе форма известна с 1943 г., интродуцирована HugoF. Hooftman, Boskoop, Голландия [17].

Pinus resinosa Ait. - Сосна смолистая. 4 экз., уч. 128, 142. Семена из природы Северной Америки, всх. 18.06.1974. Уч. 142 (3 экз.) пос. 29.04.1988. Уч. 128: пересажена с уч. 133 в 1997 г. (на уч. 133 пос. в 1983 г. в возрасте 9 лет). Пл. В Саду: 1879-1887, 1948по настоящее время [9]. В Санкт-Петербурге на питомнике Регеля - Кессельринга с 1878 г. 
[12]. Одна из самых важных сосен Северной Америки как источник деловой древесины.

Pinus sibirica Du Tour - Сосна кедровая сибирская. 7 экз. Самое старое дерево на уч. 36: возраст около 110 лет, из двух деревьев одно засохло, второе тоже в плохом состоянии, вероятно из-за фитофторы. Уч. 127 (3 экз.): пос. до 1934 г.; принимая во внимание данные инвентаризации 1981 г. сейчас около 85 лет. Уч. 77: более молодой послевоенный экз., всх. 1947 г., пос. 2.10.1967 [4]. Уч. 94 (2 экз.): растение (3-летний сеянец) от В.И. Дорофеева из природы республики Алтай, верховья р. Чуя, каменистая осыпь, $\sim 1700$ м н.у.м., сбор в 1995 г., пос. 2007 г. и 2013 г. Пл., выращивается из местных семян. Один из первых древесных экзотов в СанктПетербурге. Вместе с местной сосной обыкновенной включена в первый Каталог Аптекарского огорода (Ботанический сад БИН), составленный первым его директором И. Сигезбеком: Pinussativasiberica, foliisviridibus, longioribus, cononuculisqueminoribus[21]. До этого применялась в Летнем саду Петра Первого. В Санкт-Петербурге стала выращиваться намного раньше, чем в садах Западной Европы. Из хвойных один из самых дымостойких видов. В Саду: 1736, 1852- по настоящее время [9], ранее не различалась от $P$. cembra. В урожайные годы шишки бывают не только вверху, но и в середине и даже в нижней части кроны.

Pinus sosnowskyi Nakai - Сосна Coсновского. 3 экз. Уч. 116: всх. 5.05.1949, пос. 1954 г. [4], до 2011 г. выращивалась под названием Pinus sylvestris. Отличается формой шишек с крючковатыми апофизами. Уч. 119: растение от Г.Т. Шевченко в 1973 г. из природы Северного Кавказа, республика Карачаево-Черкесия, Тебердинский заповедник. Уч. 77: семенное потомство БИН, с уч. 119, всх. 2000 г., пос. 2011 г. Пл. В Саду: 1939-?, 1949 - по настоящее время [9]. Введена в культуру недавно, вероятно отсутствует в западноевропейских коллекциях, не приводится в справочниках $[13,16,17]$. Дерево выше 35 м выс., близка к сосне обыкновенной, замещает её на Кавказе, где в районах с более континентальным климатом образует светлохвойные леса, теперь сильно истреблённые. В горы поднимается до 2600 м. На юге ареал заходит в Турцию и Иран. Очень засухоустойчива, представляет интерес для разведения на сухих местах и бедных почвах. У себя на родине преставляет особую ценность как порода, создающая леса курортного значения [12].

Pinus strobes L. - Сосна Веймутова. 4 экз. По данным инв. 1981 г. самое старое дерево на уч. 49: 125 лет. Уч. 131: 75 лет. Уч. 36 (из трёх сохранились 2 шт.): всх. 15.08.1949, пос. 10.09.1964 [4]. В Саду: $1793-$ по настоящее время, в открытом грунте постоянна, хотя в прошлом отмечались многочисленные поломки посетителями парка декоративных экземпляров, часто требовалась замена молодых посадок и неоднократные возобновления на питомниках [9]. В природных условиях Северной Америки лучшие деревья достигают 67 м выс. [13]. Ценное дерево для парков, особенно при одиночной посадке. Однако гораздо более восприимчива к болезням и поэтому менее распространена в культуре по сравнению с $P$. реисе[12].

Pinus sylvestris L. - Сосна обыкновенная. 6 экз. Самое старое дерево на уч. 118: 95 лет, один из символов Сада - вид на вестибюль оранжерей на фоне этого дерева печатается на изданиях Ботанического сада Петра Великого. Уч. 76: возраст около 75 лет. Уч. 77 (3 экз.): всх. 1959 г. [4]. Уч. 94: всх. 1950, пос. 12.10.1956 [4]. Вид местной флоры. Пл. Плохо растёт в центре города. В последние годы на хвое и побегах обнаружен хермес. В Саду: 1736, 1796- по настоящее время [9]. В культуре с давних времён [20]. Самая распространённая из сосен мира, имеет наибольший ареал, от Атлантического до Тихого океана, и от Испании до севера Норвегии; и второе среди всех хвойных вообще после Juniperuscommunis L.

Pinus sylvestris L. var. cretacea (Kalenicz.) Kondr. - Сосна обыкновенная, разн. меловая. 1 экз., уч. 56. Растение из природы Белгородской обл. от А.В. Волчанской, окрест. посёлка Щебекино, в 2010 г. Пос. 2013 г. Цветение в Саду ранее не отмечалось, были попытки в 2004 г. [14], но тогда привезённые саженцы из Воронежской обл. не прижились. В культуре недавно и очень редко, только в России и Украине. Входит в Красную книгу РФ [6]. 
Pinus sylvestris L. f. Parvifolia Carriere Сосна обыкновенная, ф. мелкохвойная. Медленнорастущая форма небольших размеров с короткой хвоёй. 2 экз., уч. 98 и 99. Семена от Л.П. Трофимука из природы Южной Карелии: остров Тулолансари Ладожского озера, на скалах, отбор из сеянцев. Всх. 2005 г. Пос. 2015 г. Вег.

Pinus tabuliformis Carr. - Сосна уплощённая, или китайская. 1 экз., уч. 17. Семена от С.Н. Горошкевича, из природы Китая, всх. 2006 г., пос. 2015 г. Введена в культуру в 1862 г. В Ботанический сад БИН впервые поступила от известного путешественника Н.М. Пржевальского из провинции Ганьсу Китая в 1887 г., неоднократно испытывалась повторно [12]. Вег.

Pinus uncinata Ramondex DC. - Сосна горная крючковатая. 2 экз., уч. 77 . Более старое дерево (экз. № 49): всх. 13.05.1959, пос. 3.10.1967 (из трёх сохранилось одно). Молодой экз. (№ 69) на том же уч., семена из природы: Франция, горы Пиренеи, всх. 2000, пос. 2014 г. Пл. В Саду: до 1852, 1887-1898, 1936 1941, 1956 - по настоящее время (Связева, 2005). В Санкт-Петербурге первым испытал Ф.Б. Фишер [11]. Вид близкий к P. mugo, однако растёт не кустом, а одноствольным деревом, отличается более длинной хвоёй, а также формой шишек. Крона густая, долго не оголяется, хвоя держится несколько лет.

Таким образом, в современной коллекции Ботанического сада Петра Великого БИН PAН в Санкт-Петербурге выращивается 27 таксонов p. Pinus, относящихся к 23 видам. 17 видов образуют шишки (хотя бы раз в несколько лет). В отличие от многих других хвойных, почти все представители этого рода в Саду зимостойки. Они устойчивы к налипанию снега, у них редко бывают морозобойные трещины ствола. Они декоративны в течение всего года и повышают привлекательность Сада для посетителей на феноэтапах от «Глубокой осени» до весны. Этим они выделяются от листопадных растений. В последние годы в условиях потепления климата у представителей рода Pinus в Саду отмечено распространение хермеса. Вначале это отмечалось на пятихвойных кедровых соснах (P. cembra, P. koraiensis, P. pumila, P. sibirica), но в последние годы хермес перешёл и на двухвойные сосны. Так, он обнаружен на ден- дропитомнике на $P$. friesiana.В вегетационный сезон 2015 г. достоверно выделен сибирский кедровый хермес (Pineus cembrae Cholodkovsky, 1888) на P. cembra (уч. 94), P. pumila (уч. 101, 128), P. sibirica (уч. 127). Чаще всего он поселяется в пазухах молодой хвои и приводит к её пожелтению, резко снижая декоративность растения. Распространению хермеса способствуют мягкие зимы в последние годы, благоприятные для перезимовки вредителей. Тем не менее, культивируемые здесь виды р. Pinusoтносятся к декоративным, устойчивым и долговечным хвойным.

Заключение. Род Pinus - один из важнейших родов древесных растений для озеленения, лесного и лесопаркового хозяйства на Северо-Западе России. В коллекции Ботанического сада Петра Великого Ботанического института им. В.Л. Комарова РАН в Санкт-Петербурге выращивается 27 видов и форм сосны (Pinus L.), представленных 82 экземплярами. Сосна Веймутова (P. strobus) образует самые крупные деревья как по высоте (25,0 м), так и по диаметру ствола (68 см). К самым старым относятся деревья P.strobus ( 125 лет) и P. sibirica ( 110 лет). Гордостью коллекции являются такие редкие восточноазиатские виды, как $P$. densiflora и $P$. densata. Сосна кедровая стланиковая (P. pumila)была впервые испытана и здесь введена в культуру. Образуют семена 17 видов р. Pinus. Среди представителей этого рода в Саду есть образцы, точно документированные и привязанные к конкретным природным популяциям. Как раз такие растения имеют важное значение с точки зрения сохранения биоразнообразия Ex-situ. Хотя история интродукции насчитывает здесь почти 300 лет, интродукционные резервы рода Pinus в Санкт-Петербурге далеко не исчерпаны. Есть виды, перспективные для повторной интродукции ( $P$. edulis Engelm, $P$. rigida Mill., P. thunbergii Parl. и др.), данные по многим испытанным в прошлом видам противоречивы. Возможно, эти виды могут быть здесь устойчивыми в условиях современного климата. Очень многие сосны никогда не испытывались и нуждаются в первичной интродукции (P. Arizonica Engelm., P. culminicola Andersenet Beaman, $P$. henryi Mast. и др.).

Необходим постоянный мониторинг, уточнение зимостойкости, а также устойчи- 
вости к болезням и вредителям в условиях изменений климата и тенденции к потеплению. Представляет большой интерес изучение особенностей семеношения и качества семян, изучение роста и развития молодых растений следующих поколений. Актуально более широкое внедрение испытанных видов в городское озеленение, лесное и лесопарковое хозяйство не только в Санкт-Петербурге, но и на Северо-Западе России.

\section{БЛАГОДАРНОСТЬ}

Авторы выражают искреннюю благодарность доктору биологических наук Стекольщикову Андрею Валерьевичу, старшему научному сотруднику Лаборатории систематики насекомых Зоологического института РАН, за помощь в определении видов хермеса на экземплярах в парке БИН РАН.

\section{ПРИМЕЧАНИЕ}

1 Работа выполнена в рамках выполнения государственного задания согласно тематическому плану Ботанического института им. В.Л. Комарова РАН по темам № 0126-2014-0021 «Коллекции живых растений Ботанического института им. В.Л. Комарова РАН (история, современное состояние, перспективы развития и использования)».

\section{СПИСОК ЛИТЕРАТУРЫ}

1. Булыгин, Н. Е. Дендрология. Фенологические наблюдения над хвойными породами / Н. Е. Булыгин. - Л. : ЛТА, 1974. - 82 с.

2. Булыгин, Н. Е. Фенологические наблюдения над древесными растениями / Н. Е. Булыгин. Л. : ЛТА, 1979. $-97 \mathrm{c}$.

3. Булыгин, Н. Е. Биологические основы дендрофенологии / Н. Е. Булыгин. - Л. : ЛТА, 1982. $80 \mathrm{c}$.

4. Головач, А. Г. Деревья, кустарники и лианы Ботанического сада БИН АН СССР (итоги интродукции) / А. Г. Головач. - Л. : Наука, 1980. - 188 с.

5. Комарова, В. Н. Пугеводитель по парку Ботанического института им. В. Л. Комарова / В. Н. Комарова, О. А. Связева, Г. А. Фирсов, А. В. Холопова. - СПб. : Изд-во «Росток», 2001. - 256 с.

6. Красная книга Российской Федерации (растения и грибы) / Гл. редколл.: Ю. П. Трутнев и др.; Сост. Р. В. Камелин и др. М. : Тов-ство науч. изд. КМК, 2008. -855 c.
7. Лапин, П. И. Сезонный ритм развития древесных растений и его значение для интродукции / П. И. Лапин // Бюл. Глав. Ботан. Сада. - 1967. Вып. 65. - С. 13-18.

8. Липский, В. И. Перечень растений, распространенных в культуре Императорским С.-Петербургским Ботаническим садом / В. И. Липский, К. К. Мейсснер // Императорский С.-Петербургский Ботанический сад за 200 лет его существования (1713-1913). Ч. 3. - Петроград, 1913-1915. - С. 537$560 \mathrm{c}$.

9. Связева, О.А. Деревья, кустарники и лианы парка Ботанического сада Ботанического институга им. В.Л. Комарова (К истории введения в культуру) / О. А. Связева. - СПб. : Росток, 2005. - 384 с.

10. Фишер, Ф.Б. Опыт разведения иностранных дерев/ Ф.Б. Фишер// Лесной журнал. - СПб., 1837. - Ч. 3. Кн. 3. - С. 442-445.

11. Фишер, Ф. Б. Деревья и кустарники, способные к разведению в окрестностях Санкт-Петербурга / Ф. Б. Фишер // Журн. МВД. - СПб., 1852.T. 40. Кн. 12. - С. $1-13$.

12. Фирсов, Г. А. Хвойные в Санкт-Петербурге / Г. А. Фирсов, Л. В. Орлова. - СПб. : Росток, 2008. $-336 \mathrm{c}$.

13. Auders, A. G. Encyclopedia of Conifers. A comprehensive Guide to Cultivars and Species / A. G. Auders, D.P. Spicer// Royal Horticultural Society. - 2012. - Vol. 1. Abies to Picea. - Vol. 2. Pilgerodendron to Xanthocyparis. $-1506 \mathrm{p}$.

14. Firsov, G. The Chalk Pine of Southern Russia / G. Firsov // The British Conifer Society Journal. Vol. 4. - Spring 2005. - pp. 15-17.

15. Grimshaw, J. New Trees: Recent Introductions to Cultivation / J. Grimshaw, R. Bayton // The Board of Trustees of the Royal Botanic Gardens, Kew and The International Dendrology Society. 2009. -976 p.

16. Hillier, J. (Consulting Editors). The Hillier manual of trees and shrubs/ J. Hillier, A. Coombes. Newton Abbot, Devon, England. David and Charles.2003. $-512 \mathrm{p}$.

17. Krussmann, G. Manual of Cultivated Conifers/ G. Krussmann. - Portland, Oregon: Timber Press, 1995. $-361 \mathrm{p}$.

18. Orlova, L. Problems in the Field of Systematics and Investigation of Conifers in Russia / L. Orlova, G. Firsov // Journal of Agricultural Science and Technology. - Vol. 3. - 2013. - pp. 880-886.

19. Petrow, J. Index Plantarum horti imperatoriae medico-chirurgicae academiae, quas secundum Synopsin Persoonii, in systematicum ordinem redegit Jason Petrow, Doctor Matque Botanices et Pharmacologiae Prof. P.O. Petropoli / J. Petrow. In Typographia Imperatoria, 1816. $-216 \mathrm{p}$.

20. Rehder, A. Manual of cultivated trees and shrubs hardy in North America / A. Rehder - 2-nd 
edition. - New York, The MacMillan Company, 1949. $996 \mathrm{p}$.

21. Siegesbeck, J.G. Primitiae Florae Petropolitanae sive Catalogus Plantarum tam indigenarum quam exoticarum, quibus instructus suit Hortus Medicus Petriburgensis per annum MDCCXXXVI/ J.G. Siegesbeck. - Rigae, 1736.-111 p.

\section{REFERENCES}

1. Buligin N.E. Dendrologija. Fenologicheskie nabludenija nad hvojnimi porodami [Dendrology. Phenological observations on conifers]. L., LTA, 1974, $82 \mathrm{p}$.

2. Buligin N.E. Fenologicheskie nabludenija nad drevesnimi rastenijami [Phenological observations on woody plants]. L., LTA, 1979, 97 p.

3. Buligin N.E. Biologicheskie osnovi dendrophenologii [Biological bases of dendrophenology]. L., LTA, 1982, 80 p.

4. Golovach A.G. Derevja, kustarniki i liani Botanicheskogo sada BIN AN SSSR (itogi introdukzii) [Trees, shrubs and lianas of Botanic Garden BIN AS USSR (results of introduction)]. L., Nauka, 1980, 188 p.

5. Komarova V.N., Svjazeva O.A., Firsov G.A., Kholopova A.V. Putevoditel po parku Botanicheskogo instituta im V.L. Komarova [Guide-book on park of the Komarov Botanical Institute]. SPb., Rostok, 2001, 256 pp.

6. Krasnaya kniga Rossijskoj Federazii (rastenija i gribi) [Red Data Book of Russian Federation (plants and fungi) / Main editorial board.: Yu. P. Trutnev et al.; compilers R.V. Kamelin et al. Moscow, KMK Publishing House, 2008, 855 pp.

7. Lapin P.I. Sezonny ritm razvitija drevesnih rastenij i ego znachenie dlja introdukzii [Seasonal rhythm of development of woody plants and its significance for introduction], Bull. MainBotan. Garden, 1967, Iss. 65, pp. 13-18.

8. Lipsky V.I., Meissner K.K. Perechen rastenij, rasprostranenih $\mathrm{v}$ kulture Imperatorskim S.Peterburgskim Botanicheskim sadom [List of plants distributed in cultivation by St.-Petersburg Botanical Garden], Imperatorsky S.-Peterburgsky Botanichesky sad za 200 let egi suschestvovanija (1713-1913). Petrograd, 1913-1915, Part 3, pp. 537-560.

9. Svjazeva O.A. Derevja, kustarniki i liani parka Botanicheskogo sada Botanicheskogo instituta im. V.L. Komarova (k istorii vvedenija v kulturu) [Trees, shrubs and lianas of Botanic Garden of the V.L. Komarov Botanical Institute (to the history of involving into cultivation). SPb., Rostok, 2005, 384 p.

10. Fischer F.B. Opit razvedenija inostrannih derev [Experience of cultivation of exotic trees], Lesnoj Journ. SPb., 1837, Part. 3, Book 3, pp. 442-445.

11. Fischer F.B. Derevja i kustarniki, sposobnie k razvedeniju v okrestnostjah Sankt-Peterburga [Trees and shrubs capable for cultivation at environs of Saint-Petersburg], Journ. MVD, no 40, Book 12, 1852, pp. 1-13.

12. Firsov G.A., Orlova L.V. Hvojnie v SanktPeterburge [Conifers at Saint-Petersburg]. SPb., Rostok, 2008, 336 p.

13. Auders A.G., Spicer D.P. Encyclopedia of Conifers. A comprehensive Guide to Cultivars and Species, Royal Horticultural Society, 2012, Vol. 1. Abies to Picea, Vol. 2. Pilgerodendron to Xanthocyparis, $1506 \mathrm{p}$.

14. Firsov G. The Chalk Pine of Southern Russia, The British Conifer Society Journal, no 4. Spring 2005, pp. 15-17.

15. Grimshaw J., Bayton R. New Trees: Recent Introductions to Cultivation. The Board ofTrustees of the Royal Botanic Gardens, Kew and The International Dendrology Society, 2009, 976 p.

16. Hillier J., Coombes A. (Consulting Editors). The Hillier manual of trees and shrubs. Newton Abbot, Devon, England, David and Charles, 2003, 512 p.

17. Krussmann G. Manual of Cultivated Conifers. Portland, Oregon, Timber Press., 1995, 361 p.

18. Orlova L., Firsov G. Problems in the Field of Systematics and Investigation of Conifers in Russia, Journal of Agricultural Science and Technology, no 3. Published December 20, 2013, pp. 880-886.

19. Petrow J. Index Plantarum horti imperatoriae medico-chirurgicae academiae, quas secundum Synopsin Persoonii, in systematicum ordinem redegit Jason Petrow, Doctor M. atque Botanices et Pharmacologiae Prof. P.O. Petropoli. In Typographia Imperatoria, 1816, 216 p.

20. Rehder A. Manual of cultivated trees and shrubs hardy in North America. 2-nd edition. New York, The MacMillan Company, 1949, 996 p.

21. Siegesbeck, J.G. Primitiae Florae Petropolitanae sive Catalogus Plantarum tam indigenarum quam exoticarum, quibus instructus suit Hortus Medicus Petriburgensis per annum MDCCXXXVI. Rigae, 1736, 111 p. 


\section{БИОЛОГИЯ И БИОТЕХНОЛОГИЯ}

\section{Information about the Authors}

Gennadiy Afanas'evich Firsov, Candidate of Sciences (Biology), Scientific Curator of Arboretum of Peter the Great Botanical Garden, Senior Researcher, V.L. Komarov Botanical Institute of the Russian Academy of Sciences, Professora Popova St., 2, 197376 Saint Petersburg, Russian Federation, gennady_firsov@mail.ru.

Alexandr Gennadjevich Khmarik, Postgraduate Student, Chair of Botany and Dendrology, Saint Petersburg State Forest-Technical University, Institutskij per., 5, 194021 Saint Petersburg, Russian Federation, hag1989@gmail.com.

\section{Информация об авторах}

Геннадий Афанасьевич Фирсов, кандидат биологических наук, научный куратор паркадендрария и дендропитомника, старший научный сотрудник, Ботанический институт им. В.Л. Комарова РАН, ул. Профессора Попова, 2, 197376 г. Санкт-Петербург, Российская Федерация, gennady_firsov@mail.ru.

Александр Геннадьевич Хмарик, аспирант кафедры ботаники и дендрологии, СанктПетербургский государственный лесотехнический университет, Институтский пер., 5, 194021 г. Санкт-Петербург, Российская Федерация, hag1989@gmail.com. 